\title{
Originals
}

\section{Residual insulin positivity and pancreatic atrophy in relation to duration of chronic Type 1 (insulin-dependent) diabetes mellitus and microangiopathy*}

\author{
M. Löhr and G.Klöppel** \\ Institute of Pathology, University of Hamburg, Hamburg, FRG
}

\begin{abstract}
Summary. The relationship of residual insulin positivity in chronic Type 1 (insulin-dependent) diabetes and atrophy of the exocrine pancreas to duration of diabetes, age at onset and microangiopathy was studied in 26 patients (disease duration 2 to 54 years, mean 26 years). Islets containing insulin cells were found in $13 / 26$ pancreata. In $5 / 13$ pancreata insulin positive cells were detected in only one lobule, while in $8 / 13$ insulin positivity was multifocal. All patients with diabetes duration less than 11 years had residual insulin cells; whereas, the rate of insulin positivity was near $40 \%$ with diabetes duration of more than 11 and 21 years, respectively. Survival of insulin cells was not clearly related to age at onset. HLA-DR expression on insulin cells was seen in one case. Insulitis was lacking. Pancreatic volume determined in 18 patients ranged from $14-110 \mathrm{ml}$ (age adjusted mean $56.3 \mathrm{ml}$ ) and was significantly less than that of control sub-
\end{abstract}

jects (age adjusted, mean $89.9 \mathrm{ml}, p<0.0001$ ). Computerized morphometry of the exocrine pancreas revealed severe acinar atrophy due to a reduction in size of acinar cells. Acinar atrophy correlated neither with the degree of insulin positivity, disease duration nor severity of microangiopathy. The findings suggest that in about $40 \%$ of patients with Type 1 diabetes a small population of insulin cells may escape autoimmune destruction, irrespective of disease duration or age at onset. Though exocrine atrophy and insulin deficiency are associated, the variable extent of pancreatic atrophy could not to be related to such factors as amount of surviving insulin cells, duration of diabetes or microangiopathy.

Key words: Chronic Type 1 (insulin-dependent) diabetes, residual insulin cells, exocrine atrophy, HLA-DR expression, diabetic microangiopathy.
Loss of insulin cells characterises the islet lesions in patients with Type 1 (insulin-dependent) diabetes mellitus [1-4]. This loss, however, need not to be complete, since B cells, though severely reduced, have been demonstrated even in patients with a diabetes duration up to 37 years $[1,3]$. The mechanisms which may protect some insulin cells from destruction by the autoimmune process underlying Type 1 diabetes are largely unknown.

Another finding that characterises the pancreas in chronic Type 1 diabetes is a reduction in weight and volume [3,5-8]. The pancreatic atrophy is attributed to the lacking trophic effect of insulin on the acinar cells $[2,3,9-13]$. The extent of the exocrine atrophy, however, appears to vary considerably from patient to patient and has not yet been related to the remaining insulin positivity in the pancreas, to diabetes duration or to the degree of microangiopathy.

\footnotetext{
* Presented in part at the 22 ${ }^{\text {nd }}$ EASD meeting in Rome, 1986

** Present address: Department of Pathology, Free University of Brussels, Belgium
}

The aim of the present study was to investigate the degree and distribution of residual insulin positivity in the pancreas of patients with long-standing Type 1 diabetes by immunocytochemistry and to determine the degree of pancreatic atrophy by morphometry. The results from these two determinations were then related to diabetes duration, age at onset and extent of microangiopathy to see whether these parameters have any impact on the survival of insulin cells and a decrease of pancreatic volume.

\section{Subjects and methods}

In 26 patients (14 males, 12 females) with Type 1 diabetes of long duration (2-54 years, mean 26 years), the pancreas and the kidneys were studied at autopsy. Autopsies were performed at varying intervals post mortem, with a range from 14 to $26 \mathrm{~h}$. Clinical data regarding age at onset and duration of diabetes were collected. Death was related to complications of diabetes, i. e. nephropathy, myocardial infarction and coma.

The pancreas was carefully dissected and in 18 cases its volume was determined by Archimedes' principle. The same was done in 
Table 1. Clinical characteristics of patients with Type 1 (insulin-dependent) diabetes with and without residual insulin cells

\begin{tabular}{|c|c|c|c|c|c|}
\hline & $\begin{array}{l}\text { Insulin- } \\
\text { score }\end{array}$ & Number & $\begin{array}{l}\text { Age } \\
\text { (years) } \\
\text { Mean士 } \\
\text { SD }\end{array}$ & $\begin{array}{l}\text { Diabetes } \\
\text { duration } \\
\text { (years) } \\
\text { Mean } \pm \\
\text { SD }\end{array}$ & $\begin{array}{l}\text { Age at } \\
\text { onset } \\
\text { (years) } \\
\text { Mean } \pm \\
\text { SD }\end{array}$ \\
\hline $\begin{array}{l}\text { Chronic Type } 1 \\
\text { diabetes } \\
\text { mellitus }\end{array}$ & $\begin{array}{l}0 \\
1+ \\
2+\end{array}$ & $\begin{array}{r}13 \\
5 \\
8\end{array}$ & $\begin{array}{l}52 \pm 15 \\
49 \pm 27 \\
41 \pm 21\end{array}$ & $\begin{array}{l}30 \pm 9 \\
27 \pm 19 \\
20 \pm 12\end{array}$ & $\begin{array}{l}23 \pm 11 \\
22 \pm 24 \\
21 \pm 14\end{array}$ \\
\hline All & & 26 & $48 \pm 19$ & $26 \pm 12$ & $22 \pm 15$ \\
\hline Control subjects & $3+$ & 19 & $40 \pm 18$ & & \\
\hline
\end{tabular}

45 nondiabetic control subjects who died of diseases unrelated to the pancreas. In 19 of these 45 patients, the pancreas was used for morphometric evaluation of the exocrine compartment. The interval between death and examination in the control subjects averaged $24 \mathrm{~h}$. The pancreas was cut into slices and fixed in Bouin's solution. Material was obtained from eight regions coded by anatomic location according to the protocol proposed by Malaisse-Lagae et al. [14]. From each block, serial sections $(3 \mu \mathrm{m})$ were cut after routine paraffin processing. The first three sections were stained with $H \& E$, periodic acid Schiff (PAS) and Masson-Goldner.

Immunocytochemistry was performed on the subsequent deparaffinised sections, as described elsewhere [15]. A monoclonal antibody was used against insulin (Biogenex via Camon, Wiesbaden, FRG) and polyclonal antibodies against glucagon (INC, International Nuclear Corporation, Stillwater, Minn, USA), somatostatin (INC) and human pancreatic polypeptide (HPP, gift of Dr. R.E.Chance, Indianapolis, Ind, USA). The primary dilutions were $1: 20,1: 5000,1: 5000$ and $1: 10000$ respectively. In addition to the hormonal antibodies, we used two antibodies against the non-polymorphous region of the HLA-DR antigen, EP 113 (gift of Dr. H.G. Thiele, Hamburg, FRG [16]) and TAL-B 5 (gift of C. Dixon, London, UK [17]) known to react on paraffin embedded tissue at dilutions of $1: 10000$ and $1: 20$ respectively.

The sections were evaluated regarding insulitis, insulin cell content of the islets and localisation and frequency of insulin positive islets in the pancreas. The presence of insulin positive islets in one lobule was graded $1+$, while insulin positive islets in more than one lobule were graded $2+$. The islets in control subjects were graded $3+$. In five pancreata (two with $1+$ insulin positivity, three with $2+$ insulin positivity) four to five randomly selected insulin positive islets were evaluated by point counting to determine the percentage of total islet surface area occupied by each of the four islet cell types. The percentages were then averaged and a group mean was calculated.

To evaluate the volume density of the acinar cell compartment in the patients with diabetes and 19 normoglycaemic normal weight control subjects, the areas occupied by the nuclei and the cytoplasm of the acinar cells were separately measured on a Masson-Goldner stained cross-sectional slide of the pancreas. The morphometric equipment included a standard light microscope (Zeiss, Oberkochen, FRG) with a semi-automatic image analyser (Kontron, München, FRG) [18]. The image of the pancreatic parenchyma, as seen in the microscope at a total magnification of $\times 63$, appeared on a color monitor and was then transformed by color-tone and grey-tone level discrimination into a black and white picture. Four different areas from the body and tail of the pancreas were arbitrarily chosen for evaluation. From the two parameters measured, the nucleus/cell (cytoplasm plus nucleus)-ratio ( $\mathrm{N} / \mathrm{C}$ ratio) was calculated. In addition, the number of nuclei per $0.5 \mathrm{~mm}^{2}$ (monitor screen area at $\times 63$ magnification) was determined.

To estimate the degree of microvascular changes, thickening of the basement membrane of capillaries and arterioles, as visualized

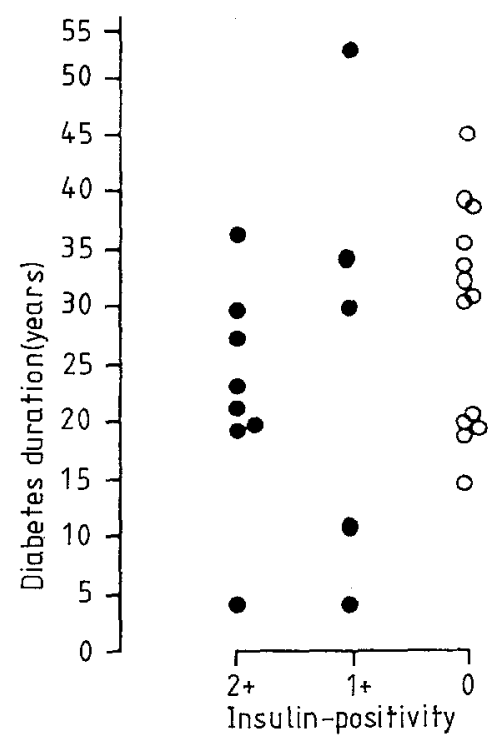

Fig. 1. Duration of Type 1 (insulin-dependent) diabetes in relation to residual insulin positivity. Insulin-scores: $O=$ insulin negative;

- insulin positive $(1+$ monofocal, $2+$ multifocal $)$

by PAS staining, was recorded separately in the pancreas and the kidneys of each patient by two reviewers independently. In the pancreas, a moderate basement membrane thickening was graded $1+$, while severe changes were recorded $2+$. In the kidneys, the microvascular alterations, i.e. glomerulosclerosis (GS), were graded according to the following scheme [19]: slightly diffuse GS (1); moderately diffuse and $<50 \%$ nodular GS (2); severely diffuse and moderate GS with $>10 \%$ hyalinosis (3); and severe GS with over $50 \%$ hyalinosis (4). Comparison of the graded vascular changes of the pancreas and kidney revealed close correlation between $1+$ pancreatic microangiopathy and GS (1) and (2), and $2+$ microangiopathy and GS (3) and (4) $(r=0.73)$.

\section{Statistical analysis}

The insulin positivity scores, the pancreatic volumes and the volume densities of the acinar cells were correlated with diabetes duration, age at onset and microvascular changes. The statistical tests to analyse these data included analysis of variance and forward stepwise multiple linear regression [20]. Differences between groups were considered to be statistically significant when a corresponding test (Kruskal-Wallis and Mann-Whitney, respectively) showed a twosided level of significance of $p<0.05$ [21].

\section{Results}

The 26 diabetic patients studied ranged in age from 12-76 years (mean 48 years). The age at onset varied from 3-65 years (mean 22 years) and the duration of diabetes from 2-54 years (mean 26 years) (Table 1 ). One patient who developed insulin-dependent diabetes at the age of 65 also suffered from hypothyroidism. In the 19 control subjects whose exocrine pancreas was evaluated by morphometry, the age ranged from 6-67 years (mean 40 years).

In 13 diabetic patients, the pancreata contained islets with insulin-producing cells. In $5 / 13$ pancreata the 
Table 2. Residual insulin positivity in long standing Type 1 (insulin-dependent) diabetes related to parameters of pancreatic atrophy

\begin{tabular}{|c|c|c|c|c|c|c|c|c|}
\hline & $\begin{array}{l}\text { Insulin- } \\
\text { score }\end{array}$ & Number & $\begin{array}{l}\text { Pancreatic } \\
\text { volume } \mathrm{a}^{\mathrm{a}} \\
\text { (ml) }\end{array}$ & $\begin{array}{l}\text { Pancreatic } \\
\text { volume } \\
\text { (age adjusted) } \\
\text { (ml) }\end{array}$ & $\begin{array}{l}\% \text { Parenchyma } \\
\text { (\% Volome } \\
\text { density) }\end{array}$ & $\begin{array}{l}\text { Parenchyma } \\
(\mathrm{ml})\end{array}$ & $\begin{array}{l}\text { Number of } \\
\text { nuclei per } \\
0.5 \mathrm{~mm}^{2}\end{array}$ & $\mathrm{~N} / \mathrm{C}$ ratio \\
\hline & & & Mean \pm SD & Mean $\pm S D$ & Mean $\pm S D$ & Mean $\pm S D$ & Mean \pm SD & Mean \pm SD \\
\hline $\begin{array}{l}\text { Chronic Type } 1 \\
\text { diabetes mellitus }\end{array}$ & $\begin{array}{l}0 \\
1+ \\
2+\end{array}$ & $\begin{array}{r}13 \\
5 \\
8\end{array}$ & $\begin{array}{l}47 \pm 25 \\
40 \pm 11 \\
35 \pm 22\end{array}$ & & $\begin{array}{l}63.7 \pm 11 \\
59.1 \pm 10 \\
63.4 \pm 10\end{array}$ & $\begin{array}{l}30.25 \pm 3.2 \\
25.64 \pm 2.6 \\
22.23 \pm 2.3\end{array}$ & $\begin{array}{l}627 \pm 305 \\
456 \pm 108 \\
545 \pm 267\end{array}$ & $\begin{array}{l}7.01 \pm 3.8 \\
3.1 \pm 1.8 \\
5.6 \pm 2.7\end{array}$ \\
\hline All & & 26 & $43 \pm 20$ & $56.3 \pm 16.7$ & $60.5 \pm 16$ & $27.28 \pm 13.9$ & $569 \pm 266$ & $5.84 \pm 3.43$ \\
\hline Control subjects & $3+$ & 19 & $86.5 \pm 33$ & $89.9 \pm 22.6$ & $85 \pm 6.7$ & $71.87 \pm 25.9$ & $1011 \pm 342$ & $9.4 \pm 2.9$ \\
\hline$p$-values & & & 0.0001 & 0.0001 & 0.0001 & 0.0001 & 0.0001 & 0.01 \\
\hline
\end{tabular}

a These values apply only to 18 patients whose pancreatic volume could be determined (Insulin-score $0: 9 / 18 ; 1+: 4 / 18 ; 2+: 5 / 18$ )

insulin positive islets were restricted to one lobule of the pancreas $(1+)$, whereas insulin-positive islets in more than one lobule $(2+)$ were found in $8 / 13$ pancreata. All $1+$ pancreata had a greater loss of B cells than the $2+$ pancreata. Insulin positive islets showed no preferred localisation in the pancreas. In the PPlobe insulin cells were always absent. The vast majority of insulin positive islets were strongly depleted of $B$ cells. In five pancreata where the percentage of each endocrine cell type was determined, the proportion of insulin cells ranged from 3 to $28 \%$ (mean 14\%), while the mean percentage of glucagon, somatostatin and PP cells was $63 \%, 17 \%$ and $6 \%$ respectively.

Insulitis could not be detected, even after serial sectioning of blocks with insulin positivity, which was done in two cases. Coexpression of insulin and HLADR was observed on $3 \mu \mathrm{m}$ serial sections in one case of a 13-year-old boy with diabetes duration of 4 years. In this case, 4 blocks showed insulin-positive cells but HLA-DR expression on B cells was only present in a few islets from the head region. HLA-DR was consistently found to be expressed on endothelial cells. Patchy interstitial lymphocytic infiltration of the exocrine pancreas was observed in $3 / 26$ patients.

Incidence and degree of insulin positivity did not correlate significantly with a diabetes duration of less or more than 21 years. Insulin positive cells were found in all 3 patients with a diabetes duration of less than 11 years (Fig. 1). Between 11 and 21 years diabetes duration, the positivity rate was $37 \%$, and over 21 years $46 \%$. No significant relationship was found between the patients' age at onset of diabetes and residual insulin positivity.

In 18 patients, the pancreatic volume ranged from 14-110 ml. Compared with the normal mean pancreatic volumes of 600 glands as reported by Rössle [22] and established in our own series of 45 age and sex matched control subjects, the values found in the diabetic patients were markedly reduced (Fig. 1). To demonstrate the finding more clearly, the volumes from the individual cases were age adjusted to the values found

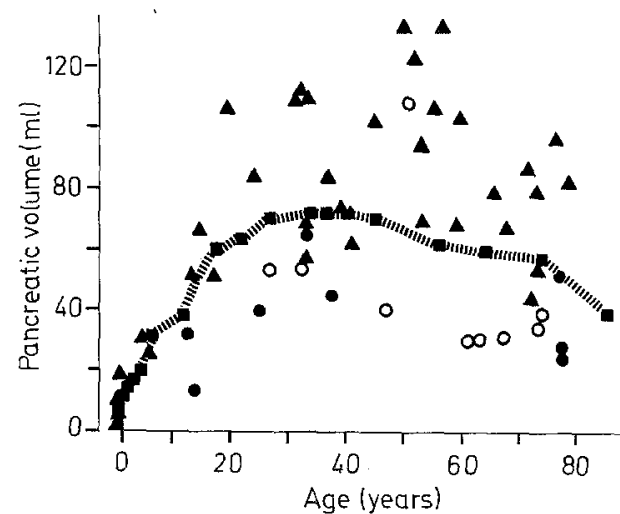

Fig. 2. Volume of the pancreas in 18 patients with chronic Type 1 diabetes $(O=$ insulin negative; $O=$ insulin positive) compared with that of 45 control subjects $(\Delta)$ and the means according to Rössle [21] (घ). Controls from the literature $(n=600)$; $\boldsymbol{\Delta}$ Controls $(n=45) ; \bigcirc$ Chronic Type 1 diabetes $(n=18)$

at the age of 35 years (peak volume) (Table 2). Significant differences were neither found between the insulin positive and negative diabetic patients nor between patients of less or more than 21 years diabetes duration. Even in those with a diabetes duration less than 11 years the pancreata were significantly smaller $(p<$ 0.0001) (Fig. 2).

In all regions of the pancreas, including the PPlobe [23], the acinar cells appeared to be smaller than those of the controls (Fig.3). The perilobular spaces, and to some degree also the interacinar spaces, were enlarged and contained loosely arranged connective tissue.

Pancreatic acinar cells surrounding islets still containing insulin cells generally showed the same degree of atrophy as those embracing insulin negative islets.

Quantitatively, the parenchymal volume (i.e. volume density $\times$ pancreatic volume in $\mathrm{ml}$ ) was significantly less in the diabetic patients with lowest values in the insulin positive categories (Table 2).

The mean values of the $\mathrm{N} / \mathrm{C}$ ratio were markedly decreased in the diabetic patients but significance in 

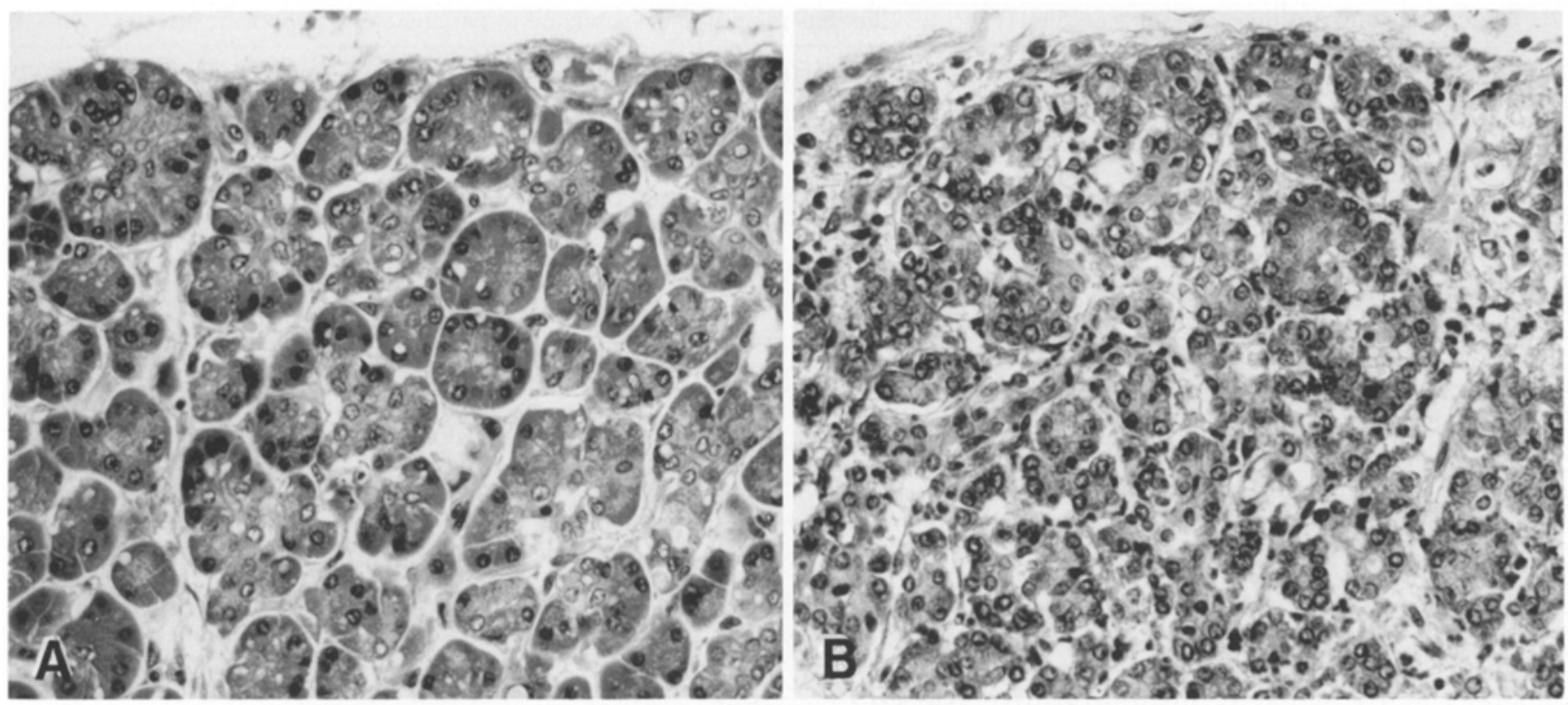

Fig. 3A and B. Comparison of pancreatic acinar tissue of a normoglycaemic patient (A) with that of a patient with chronic Type 1 diabetes (B) reveals conspicuous atrophy of the acinar cells in the diabetic pancreas. Masson-Goldner, $\times 250$

the differences to the control subjects was only reached in the insulin positive cases (Table 2). No differences were found between the insulin positive and insulin negative cases. The number of nuclei $/ 0.5 \mathrm{~mm}^{2}$ was decreased in all diabetic groups but was lowest in the insulin positive cases when compared with controls (Table 2).

With regard to microangiopathy in the pancreas and the kidney, $3 / 26$ had zero, 11 had $1+$ and 12 had $2+$ microvascular changes. There was no correlation between microangiopathy and the duration of diabetes or the degree of insulin positivity.

\section{Discussion}

The results of our study confirm and extend earlier observations showing that insulin cells, though severely reduced in number, may be present in the pancreata of patients with long standing Type 1 diabetes even decades after disease onset [1-2]. Small clusters of islets containing a few insulin cells were found in $50 \%$ $(13 / 26)$ of our patients. This percentage of insulin positive patients, though presumably somewhat underestimated because of incompleteness of our screening technique, is still greater than that found in studies on C-peptide secretion in chronic Type 1 diabetes. Measurable C-peptide levels were found in $15 \%$ to $24 \%$ of patients with a diabetes duration of more than 10 and 18 years respectively [24-25]. The most likely explanation for this discrepancy is that only those patients with multifocal residual insulin positivity are capable of secreting sufficient amounts of C-peptide to be measured. Thus, if we consider only our patients with disease duration over 11 years and multifocal insulin pos- itivity, the percentage of positive cases (about 30\%) compares better with those of C-peptide secreting patients with Type 1 diabetes. It is clear that these correlations are far from satisfactory, since our method of quantifying the remaining insulin cells allows only a rough estimation of their mass. However, considering the non-random distribution of the surviving insulin cells in the pancreas, we refrained from calculating the insulin cell volume by sophisticated stereologic techniques because such calculations would lead to irrelevant results.

Presence or absence of insulin cells in chronic Type 1 diabetes could not be related to the age at onset, but showed a certain dependency on diabetes duration. In the study of Gepts and DeMey [1], B cells were found in $50 \%$ of patients with an insulin-dependent diabetes of less than 11 years duration and in 18\% of those with a longer duration. From these data it appears that the longer the diabetes lasts the smaller the chance for survival of B cells. This view is also supported by our study, since all patients with a diabetes duration of less than 11 years still had insulin cells in their pancreata. However, when we extended the diabetes duration beyond the 11 year level and compared patients whose diabetes had lasted 10 to 21 or more than 21 years, a relationship between disease duration and survival of insulin cells no longer existed. Thus, it may be speculated that probably most of the patients whose pancreata still contain insulin cells after a diabetes duration of 10 to 20 years, will retain these insulin cells for the rest of their lives.

Since insulin positive islets had not totally disappeared from cases with extremely long disease duration, it seems that these insulin cells had escaped destruction by immune mechanisms thought to be active 
in Type 1 diabetes [26]. One of the factors under recent investigation is an aberrant HLA-DR expression on $B$ cells which is thought to be involved in the induction of the autoimmune process and possibly precedes insulitis [26-28]. In our series of 13 insulin positive patients, we found no insulitis and in only one patient coexpression of insulin and HLA-DR in very few islet cells. There are two hypotheses which might explain the phenomenon of long surviving insulin cells. Either these residual insulin cells had never expressed HLADR and have to be considered as remnants of an originally HLA-DR free B-cell population or they represent regenerated $B$ cells which no longer express HLA-DR [26]. Though there is as yet no ready explanation for the longtime survival of insulin cells, this observation is of interest with respect to the theoretical possibility to reactivate the growth of this resting pool of B cells.

Patients with chronic Type 1 diabetes display a considerable reduction in weight and volume of the pancreas $[1,6-8]$. These findings are confirmed by our study, since all but one pancreas of our series showed volume values far below those found in nondiabetic subjects [22]. This volume reduction of the pancreas was found to be due to a severe atrophy of all acinar cells (including those of the PP-lobe), since the reduction in parenchymal volume was paralleled by a decline in cell numbers per given area (expressed as nuclei per $0.5 \mathrm{~mm}^{2}$ ). The fact that in the diabetic pancreata the acinar cells, despite their smaller size, did not increase in number per area can be explained by the development of a diffuse interstitial fibrosis conspicuously enlarging the interstitial spaces. A comparison of the ratio of the nuclear area to the acinar cell area $(\mathrm{N} / \mathrm{C}$ ratio) of control subjects with that in diabetic patients showed that the decrease in cell size was particularly due to a decline of the nuclear volume.

Lack of endogenous insulin has been suggested as causing the atrophy of the pancreas in chronic Type 1 diabetes [12, 29-31], as insulin has been shown to promote growth and protein synthesis of the acinar cells $[11-13,30]$. This conclusion is substantiated by clinical studies on the exocrine secretory capacity of the pancreas in chronic Type 1 diabetes demonstrating decreased secretion of enzymes [32-36]. Frier et al. found that the preservation of pancreatic function correlates with the duration of diabetes [32] and the persistence of B-cell secretory activity measured by C-peptide levels [33]. Domschke et al. [34] and Lankisch et al. [35], however, were not able to confirm these correlations. Our results are more in keeping with the latter observations, since we failed to demonstrate clear relationships between the extent of exocrine atrophy and residual insulin positivity, the age at onset or duration of diabetes. This suggests that insulin secretion from a few remaining insulin cells is not sufficient to exert a significant trophic effect on the acinar cells.

As a further factor which may influence pancreatic exocrine atrophy, microangiopathy has to be dis- cussed. In our study, however, microangiopathy, as judged by the degree of renal glomerulosclerosis and pancreatic arteriosclerosis, was found to be unrelated to the extent of exocrine atrophy and thus seems to play no significant role in the pathogenesis of pancreatic atrophy in chronic Type 1 diabetes.

In conclusion, we demonstrated persisting residual insulin positivity in about $40 \%$ of patients with Type 1 diabetes after a disease duration of more than 11 years. Exocrine atrophy, though closely linked to a state of insulin deficiency, appeared not to be further influenced by such variables as surviving insulin cells, diabetes duration or microangiopathy.

Acknowledgments. We would like to express our sincere thanks to Ms. S. Peters, Ms. R. Malik and Ms. L. Blaudzun for their excellent technical assistance. We are thankful to Prof. G. Delling, Institute of Pathology, Univ. of Hamburg, for the collaboration regarding the morphometric evaluation. We thank Ms. U.Roggenbuck and Dr. W. Rehpenning for their help regarding statistical analysis of the data. Sincere thanks are also due to Dr. A. Foulis, Glasgow, for his help in the analysis of the HLA-DR stained sections.

\section{References}

1. Gepts W, Demey J (1978) Islet cell survival determined by morphology. An immunocytochemical study of the islets of Langerhans in juvenile diabetes mellitus. Diabetes 27 [Suppl 1]: 251-261

2. Foulis AK, Liddle CN, Farquharson MA, Richmond JA, Weir RS (1986) The histopathology of the pancreas in Type 1 (insulindependent) diabetes mellitus: a 25-year review of deaths in patients under 20 years of age in the United Kingdom. Diabetologia 29: $267-274$

3. Klöppel G (1984) Islet histopathology in diabetes mellitus. In: Klöppel G, Heitz PhU (eds) Pancreatic pathology. Churchill Livingstone, London, pp 154-192

4. Klöppel G, Löhr M, Habich K, Oberholzer M, Heitz PhU (1985) Islet pathology and the pathogenesis of type 1 and 2 diabetes revisited. Surv Synth Path Res 4: 110-125

5. Gepts W (1965) Pathologic anatomy of the pancreas in juvenile diabetes mellitus. Diabetes 14: 619-633

6. Doniach I (1974) Pathology of the islets of Langerhans in diabetes mellitus. In: Bastenie PA, Gepts W, Addison GM (eds) Immunity and autoimmunity in diabetes mellitus. Excerpta Medica, Amsterdam New York, pp 175-182

7. MacLean N, Ogilvie RF (1955) Quantitative estimation of the pancreatic islet tissue in diabetic subjects. Diabetes $4: 367-376$

8. MacLean N, Ogilvie RF (1959) Observations on the pancreatic islet tissue of young diabetic subjects. Diabetes 8: 83-91

9. Foulis AK, Stewart JA (1984) The pancreas in recent onset Type 1 (insulin-dependent) diabetes mellitus: insulin content of islets, insulitis and associated changes in the exocrine acinar tissue. Diabetologia 26: 456-461

10. Gepts W (1981) Islet changes in human diabetes. In: Cooperstein SJ, Watkins D (eds) The islets of Langerhans. Academic Press, London, pp 321-356

11. Adler G, Kern HF (1975) Regulation of exocrine pancreatic secretory process by insulin. Horm Metab Res 7: 290-296

12. Henderson JR, Daniel PM, Fraser PA (1981) The pancreas as a single organ: the influence of the endocrine upon the exocrine part of the gland. Gut 22:158-167

13. Korc M, Owerbach D, Quinto C, Rutter WJ (1981) Pancreatic islet-acinar cell interaction: amylase messanger RNA levels are determined by insulin. Science 213: 351-353

14. Malaisse-Lagae F, Stefan Y, Cox J, Perrelet A, Orci L (1979) 
Identification of a lobe rich in pancreatic polypeptide. Diabetologia 17:361-365

15. Klöppel G, Drenck CR, Oberholzer M, Heitz PhU (1984) Morphometric evidence for a striking B-cell reduction at the clinical onset of type 1 diabetes. Virchows Arch [A] 403: 441-452

16. Becker WM, Gröning G, Arndt R, Thiele HG (1981) Monoclonal antibody EP 113 raised against Reh cells recognizes a subspecies of Ia like antigens shared by $\mathrm{CALL}^{+}$and B-cell lines. In: Knapp W (ed) Leucemia Markers. Academic Press, London

17. Epenetos AA, Bobrow LG, Adams TE, Collins CM, Isaacson PG, Bodmer WF (1985) A monoclonal antibody that detects HLA-D region antigen in routinely fixed, wax embedded sections of normal and neoplastic lymphoid tissues. J Clin Pathol 38: $12-17$

18. Aherne WA, Dunnill MS (1982) Morphometry. Edward Arnold, London

19. Bloodworth JMB jr (1978) A re-evaluation of diabetic glomerulosclerosis 50 years after the discovery of insulin. Hum Pathol 9: 439-453

20. Dixon WJ (Chief Editor) (1983) BMDP Statistical software. Univ. of California Press, Berkeley, California

21. Sachs L (1984) Angewandte Statistik: Statistische Methoden und ihre Anwendungen. Springer Verlag, Berlin Heidelberg New York

22. Rössle R (1921) Beiträge zur Kenntnis der gesunden und kranken Bauchspeicheldrüse. Beitr Pathol Anat Allg Pathol 69: 163-184

23. Rahier J, Wallon J, Loozen S, Lefevre A, Gepts W, Haot J (1983) The pancreatic polypeptide cells in the human pancreas: the effect of age and diabetes. J Clin Endocrinol Metab 56: 441-444

24. Madsbad S (1983) Prevalence of residual B-cell function and its metabolic consequences in Type 1 (insulin-dependent) diabetes. Diabetologia 24: 141-147

25. Eff C, Faber O, Deckert T (1978) Persistent insulin secretion, assessed by plasma C-peptide estimation in long-term juvenile diabetics with a low insulin requirement. Diabetologia 15: 169-172

26. Bottazzo GF, Dean BM, McNally JM, Mackay EH, Swift PGF, Gamble DR (1985) In situ characterization of autoimmune phenomena and expression of HLA molecules in the pancreas in diabetic insulitis. N Engl J Med 313: 353-360
27. Foulis AK, Farquharson MA (1986) Aberrant expression of HLA-DR antigens by insulin-containing $\beta$-cells in recent-onset type 1 diabetes mellitus. Diabetes 35: 1215-1224

28. Foulis AK (1986) Class II major histocompatibility complex and organ specific autoimmunity in man. J Pathol 150: 5-11

29. Malaisse-Lagae F, Ravazzola M, Robberecht P, Vandermeers A, Malaisse WJ, Orci L (1975) Exocrine pancreas: evidence for topographic partition of secretory function. Science 190: 795-797

30. Mössner J, Logsdon CD, Williams JA, Goldfine ID (1985) Insulin via its receptors regulates growth and amylase synthesis in pancreatic acinar cells. Diabetes 34: 891-897

31. Williams JA, Goldfine ID (1985) The insulin pancreatic acinar axis: a review. Diabetes 34: $980-986$

32. Frier BM, Saunders JHB, Wormsley K, Bouchier IAD (1976) Exocrine pancreatic function in juvenile-onset diabetes mellitus. Gut 17:695-691

33. Frier BM, Faber OK, Binder C, Elliot HL (1978) The effect of residual insulin secretion on exocrine pancreatic function in juvenile onset diabetes mellitus. Diabetologia 14: 301-304

34. Domschke W, Tymper F, Domschke S, Demling L (1975) Exocrine pancreatic function in juvenile diabetics. J Dig Dis 20: 309-312

35. Lankisch PG, Manthey G, Otto J, Koop H, Talaulicar M, Willms B, Creutzfeldt W (1982) Exocrine pancreatic function in insulin-dependent diabetes mellitus. Digestion 25: 211-216

36. Hitanant S, Vanasaeng S, Tan-Ngarm-Trong D, Plengvanit $U$, Viranuvatti V (1986) Exocrine pancreatic function among diabetic patients in Thailand. Am J Gastroenterol 81: 559-561

Received: 10 June 1987

and in revised form: 21 August 1987

Professor Günter Klöppel

Department of Pathology

Free University of Brussels

Laarbeeklaan 101

B-1090 Brussels

Belgium 